\title{
The U-Pb zircon and baddeleyite ages of the Neoproterozoic Volyn Large Igneous Province: implication for the age of the magmatism and the nature of a crustal contaminant
}

\author{
Leonid Shumlyanskyy, Anna Nosova, Kjell Billström, Ulf Söderlund, Per- \\ Gunnar Andréasson \& Oksana Kuzmenkova
}

To cite this article: Leonid Shumlyanskyy, Anna Nosova, Kjell Billström, Ulf Söderlund, Per-Gunnar Andréasson \& Oksana Kuzmenkova (2016) The U-Pb zircon and baddeleyite ages of the Neoproterozoic Volyn Large Igneous Province: implication for the age of the magmatism and the nature of a crustal contaminant, GFF, 138:1, 17-30, DOI: 10.1080/11035897.2015.1123289

To link to this article: http://dx.doi.org/10.1080/11035897.2015.1123289

曲 Published online: 08 Jan 2016.

LII Article views: 27

View Crossmark data \lceil
Submit your article to this journal 주

View related articles $\nearrow$

Citing articles: 1 View citing articles $\llbracket$ 


\title{
The U-Pb zircon and baddeleyite ages of the Neoproterozoic Volyn Large Igneous Province: implication for the age of the magmatism and the nature of a crustal contaminant
}

\author{
LEONID SHUMLYANSKYY ${ }^{1}$, ANNA NOSOVA ${ }^{2}$, KJELL BILLSTRÖM ${ }^{3}$, ULF SÖDERLUND ${ }^{3,4}$, \\ PER-GUNNAR ANDRÉASSON ${ }^{4}$ and OKSANA KUZMENKOVA ${ }^{5}$
}

Shumlyanskyy, L., Nosova, A., Billström K., Söderlund U., Andréasson, P.-G. \& Kuzmenkova, O., 2016: The $\mathrm{U}-\mathrm{Pb}$ zircon and baddeleyite ages of the Neoproterozoic Volyn Large Igneous Province: implication for the age of the magmatism and the nature of a crustal contaminant. GFF, Vol. 138, No. 1, pp. 17-30. (C) Geologiska Föreningen. doi: http://dx.doi.org/10.1080/11035897.2015.1123289.

\begin{abstract}
The Volyn continental flood basalt province is situated on the western margin of the East European platform and constitutes a significant portion of the passive continental margin sequence formed along the Trans-European Suture Zone in response to Rodinia break-up in the Neoproterozoic. In Ukraine, the volcanogenic sequence is subdivided into suites called Zabolottya, Babyne and Ratne, which together with the lowermost terrigeneous Gorbashy suite comprise the Volyn series. Magmatic zircons from one high-Ti basalt sample yielded an age of $573 \pm 14 \mathrm{Ma}$, whereas grains isolated from a rhyolitic dacite yielded an age of $571 \pm 13 \mathrm{Ma}$. Baddeleyite from the olivine dolerite sample gave an older ${ }^{206} \mathrm{~Pb} /{ }^{238} \mathrm{U}$ age of $626 \pm 17 \mathrm{Ma}$, whereas the ${ }^{207} \mathrm{~Pb} /{ }^{206} \mathrm{~Pb}$ weighted average age of $567 \pm 61 \mathrm{Ma}$ is close to the zircon ages. Zircons separated from the other basaltic samples are much older and crystallized at c. 1290, 1470, 1820-1860, 1930-2050 and 2660 Ma. Ages in the 1820-1860 and 1930-2050 Ma time spans correspond to the ages of the Precambrian basement that underlies the Volyn province. However, the sources for the 1290, 1470 and 2660 Ma zircons are unknown, and these zircons must have been derived from more distal areas.
\end{abstract}

Keywords: Volyn; basalts; Vendian; zircon; baddeleyite; geochronology

${ }^{1}$ Institute of Geochemistry, Mineralogy and Ore Formation of the National Academy of Sciences of Ukraine, Palladina ave. 34, 03680, Kyiv, Ukraine, lshumlyanskyy@yahoo.com;

${ }^{2}$ Institute of Geology of Ore Deposits, Petrography, Mineralogy and Geochemistry, Russian Academy of Sciences, Staromonetny per., 35, 109017, Moscow, Russia, nosova@igem.ru;

${ }^{3}$ Department for Geological Sciences, Swedish Museum of Natural History, P.O. Box 50 007, SE-10405 Stockholm,Sweden, kjell.billstrom@nrm.se;

${ }^{4}$ Department of Geology, Lithosphere and Paleobiosphere Sciences, Geobiosphere Science Centre, Sölvegatan 12,SE-22362 Lund, Sweden, per-gunnar.andreasson@geol.lu.se; Ulf.Soderlund@geol.lu.se;

${ }^{5}$ Belorussian Scientific Research Geological Institute, Kuprievicha st., 7, Minsk 220141, Belarus, tolsty23@ mail.ru

Manuscript received 02 February 2015; accepted 17 November 2015.

\section{Introduction}

Continental flood basalts are often related to the break-up of supercontinents such as Gondwana and Pangaea in Phanerozoic times or Rodinia in Late Neoproterozoic time and commonly associated with volcanic rifted margins (Ernst et al. 2005; Ernst 2014 and references therein) that often appear on opposite sides of the ocean basins that have formed during continental break-up. However, in older continents, former volcanic rifted margins may now constitute the inner portions of large continental plates. One such palaeomargin is confined to the Trans-European Suture Zone (TESZ; Fig. 1). Being mainly amagmatic, the TESZ nevertheless contains a few important magmatic provinces one of which is the Volyn continental flood basalt province, or Volyn Large Igneous Province, that is located in western Ukraine, eastern Poland and southern Belarus occupying an area over $200,000 \mathrm{~km}^{2}$. This province, although situated in the inner part of the European continent and rather small in size, occurs as a typical continental flood basalt province related to the Neoproterozoic break-up of Rodinia supercontinent and separation of Baltica and Amazonia.

$\mathrm{U}-\mathrm{Pb}$ dating of U-bearing minerals separated from mafic rocks (gabbro, dolerites and basalts) has proved efficient to 


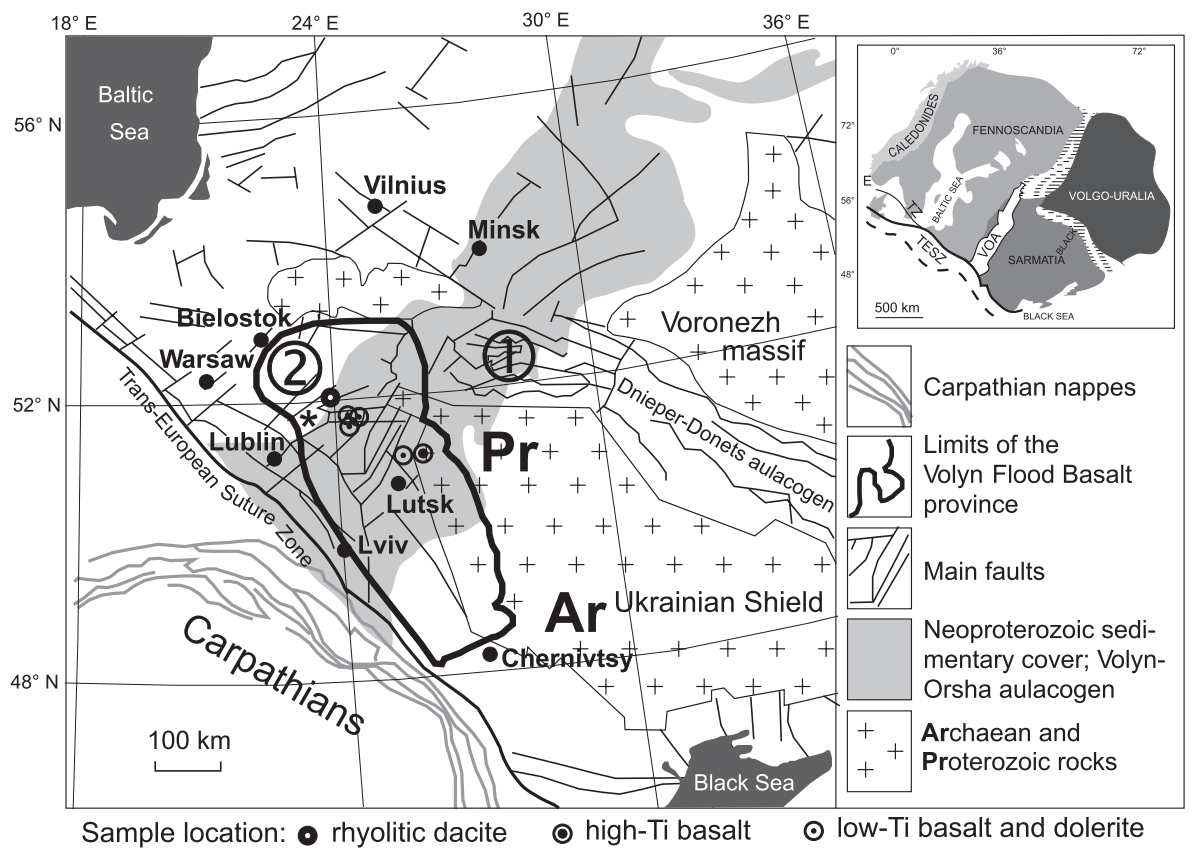

Fig. 1. Schematic map of distribution of the Volyn flood basalts. Asterisk indicates location of the Compston et al. (1995) sample. Numbers in circles: 1 - Devonian Prypyat aulacogen; 2 - Brest depression. Ar - Archaean Dniester-Bug domain of the Ukrainian shield; Pr - Palaeoproterozoic domain. Area located to the west of the Ukrainian shield is known as Volyno-Podolian monocline. Inset map: VOA indicates Volyn-Orsha depression; E stands for Egersund dyke swarm and TZ - for Tornquist zone.

produce reliable geochronological information (see for instance Kamo et al. 1989; Bingen et al. 1998; Wingate et al. 1998). Two dateable minerals that may occur in mafic rocks are baddeleyite and zircon. Baddeleyite is considered as a syn-magmatic mineral and is common in slowly cooled mafic rocks such as gabbro and coarse dolerite, while such rocks usually are too silica-poor to crystallize zircons. However, syngenetic zircon can be found in pods of diorite or even granite material in mafic intrusions and thick dykes (Svenningsen 2001; Shumlyanskyy et al. 2008; Shumlyanskyy \& Zagnitko 2010). Zircon may also be found as a syn-genetic mineral in a variety of continental flood basalt related effusive rocks including basalt, rhyodacite and quartz latite (Pinto et al. 2011). It must be recalled that mafic magmatic rocks may contain xenocrystic zircon captured en route to the place of ultimate crystallization or picked up at the source region. For instance, Zheng et al. (2011) used zircons separated from mafic rocks in the Cathaysia Block, South China, to demonstrate the presence of unexposed Archaean rocks. Similarly, Hodych et al. (2004) used U-Pb ages of zircons separated from basaltic and trachytic flows of the Skinner Cove Formation, western Newfoundland, to prove not only their Late Neoproterozoic age, but also to demonstrate its relation to the Laurentia continent.

The age of the Volyn flood basalt province remains poorly constrained (see below) which is complicating the correlation of this province with other manifestations of igneous activity that were related to the break-up of the Rodinia supercontinent and the understanding of the process of break-up. The knowledge about the age of the Volyn province is also essential in order to gain further insights into the evolution of the western part of the East European craton in the Neoproterozoic. In this article, we consider new in situ ion microprobe $\mathrm{U}-\mathrm{Pb}$ ages on zircons from basalts, dolerites and felsic volcanic rocks of the Volyn flood basalt province, and baddeleyite multigrain thermal ionization mass-spectrometry
(TIMS) U-Pb data in order to constrain the time of their eruption and of the continental break-up. However, analyses have also revealed the presence of much older, Proterozoic-Archaean, zircons in both mafic and felsic rocks of the Volyn province. We use these results to understand the origin and nature of an inferred old crustal component in the basaltic and felsic melts.

\section{Tectonic setting}

The Volyn flood basalt province is located on the western margin of the East European platform, where it straddles the boundary between two main segments of Baltica, namely Sarmatia and Fennoscandia (Fig. 1). In the Sarmatian part of the province (Fig. 2), the basement is represented by two orogenic belts - Zhytomyr (ca. 2.10-2.04 Ga) and Osnitsk-Mikashevychi (ca. 2.00-1.97 Ga) that developed on the margin of the Archaean Bug terrain (Scherbak et al. 2008). This part was later influenced by the collision with Fennoscandia as reflected in the formation of the extensive 1.81$1.74 \mathrm{Ga}$ old Korosten anorthosite-mangerite-charnokite-granite plutonic complex (Amelin et al. 1994; Bogdanova et al. 2004). The Fennoscandian part of the basement that underlies the Volyn province consists of 2.00-1.90 Ga rocks of the Central Belarus belt and, to a lesser extent, 1.85-1.79 Ga rocks of the Baltic-Belarus granulite belt (Claesson et al. 2001). These rocks have experienced some influence of a magmatic event at 1.54-1.45 Ga which resulted in the formation of the Mazury anorthosite-mangeritecharnokite-granite complex (Skridlaite et al. 2006).

\section{Regional stratigraphy}

The Palaeoproterozoic basement of the western East European platform is overlain by a platform sedimentary cover that includes 


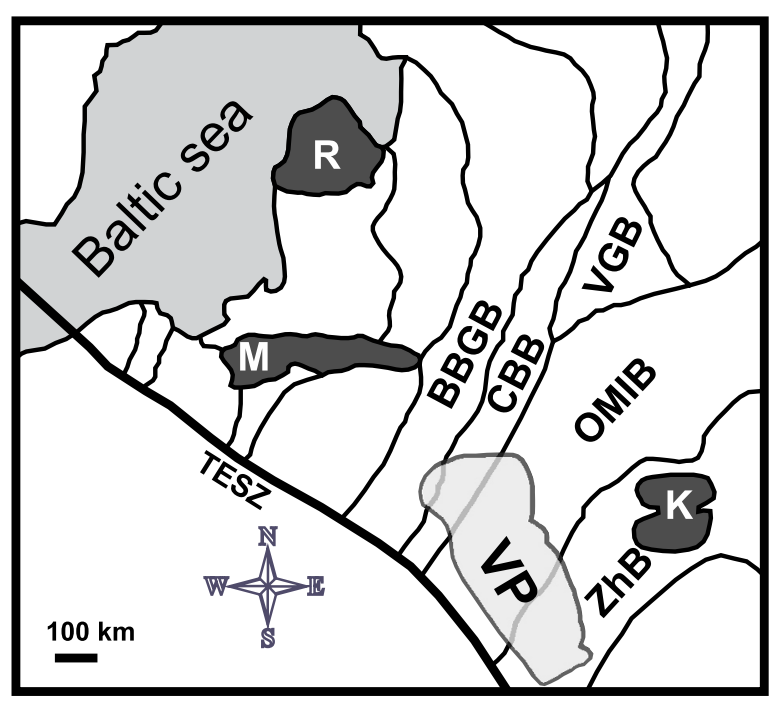

Fig. 2. Schematic map showing the relationship between Volyn flood basalts and the basement structure. Zhytomyr Belt (ZhB, c. $2.1 \mathrm{Ga})$, Osnitsk-Mikashevychi Igneous Belt (OMIB, c. 2.0 Ga), Central Belarus Belt (CBB, c. 2.0-1.9 Ga), Vitebsk Granulite Belt (VGB, c. 1.9-1.8 Ga), Belarus-Baltic Granulite Belt (BBGB, c. 1.85-1.79 Ga) and East-Lithuanian Belt (ELB, c. 1.85-1.79 Ga) are shown on the map. Korosten (1.82-1.74 Ga, K), Mazury (1.54-1.45 Ga, M), and Riga (1.58 Ga, R) anorthosite-mangerite-charnokite-granite complexes are also shown. TESZ - Trans-European Suture Zone. Basement map is simplified after Claesson et al. (2001) and Krzeminska et al. (2005). VP stands for the Volyn continental flood basalt province.

Riphean, Vendian, Early Palaeozoic, Devonian, Carboniferous and Jurassic deposits, which are almost everywhere covered by Cretaceous sediments (Kruglov \& Tsypko 1988; Poprawa \& Pacześna 2002). The thickness of the sedimentary cover is variable: it does not exceed a few tens of metres in the Belarusian massif or even a few metres in parts of the Ukrainian shield, but increases westwards to reach more than $8000 \mathrm{~m}$ at the margin of the East European platform. The slope of these sediments is generally very gentle $\left(0.5-1.0^{\circ}\right)$. In Ukraine, this monocline, known as Volyno-Podolian, is tilted from the Ukrainian shield towards the TESZ (Fig. 1).

In the south-western part of the platform, the sedimentary cover can be subdivided into two parts that fill different depressions (Fig. 3). The lower part comprises the Polissya Series and glacial Early Vendian deposits and fills out the middle-late Riphean Volyn-Orsha depression which is oriented at an oblique angle to TESZ (Fig. 1). The Polissya Series includes red sandstones and siltstones with minor amounts of clays. It is characterized by horizontal bedding, fine banding and rhythmical sedimentation and reaches $835 \mathrm{~m}$ thickness at the axis of the depression (Vlasov et al. 1972). The youngest detrital zircon found in the Polissya Series sandstone is $1018 \pm 20 \mathrm{Ma}\left({ }^{207} \mathrm{~Pb} /{ }^{206} \mathrm{~Pb}\right.$ age, Shumlyanskyy et al. 2015). Glacial Early Vendian deposits (Brody suite) are reddish-brown clay-silt-sandy unstratified rocks with a massive structure varying in thickness from 15 to $44 \mathrm{~m}$ (Nitke et al. 1976). The second (upper) part of the sedimentary cover starts with the Volyn Series that overlies the Riphean-Early Vendian sediments and fills out a tectonic depression that developed along a NWSE direction, parallel with the TESZ in a passive continental margin setting (Poprawa \& Pacześna 2002). Rocks of the Volyn

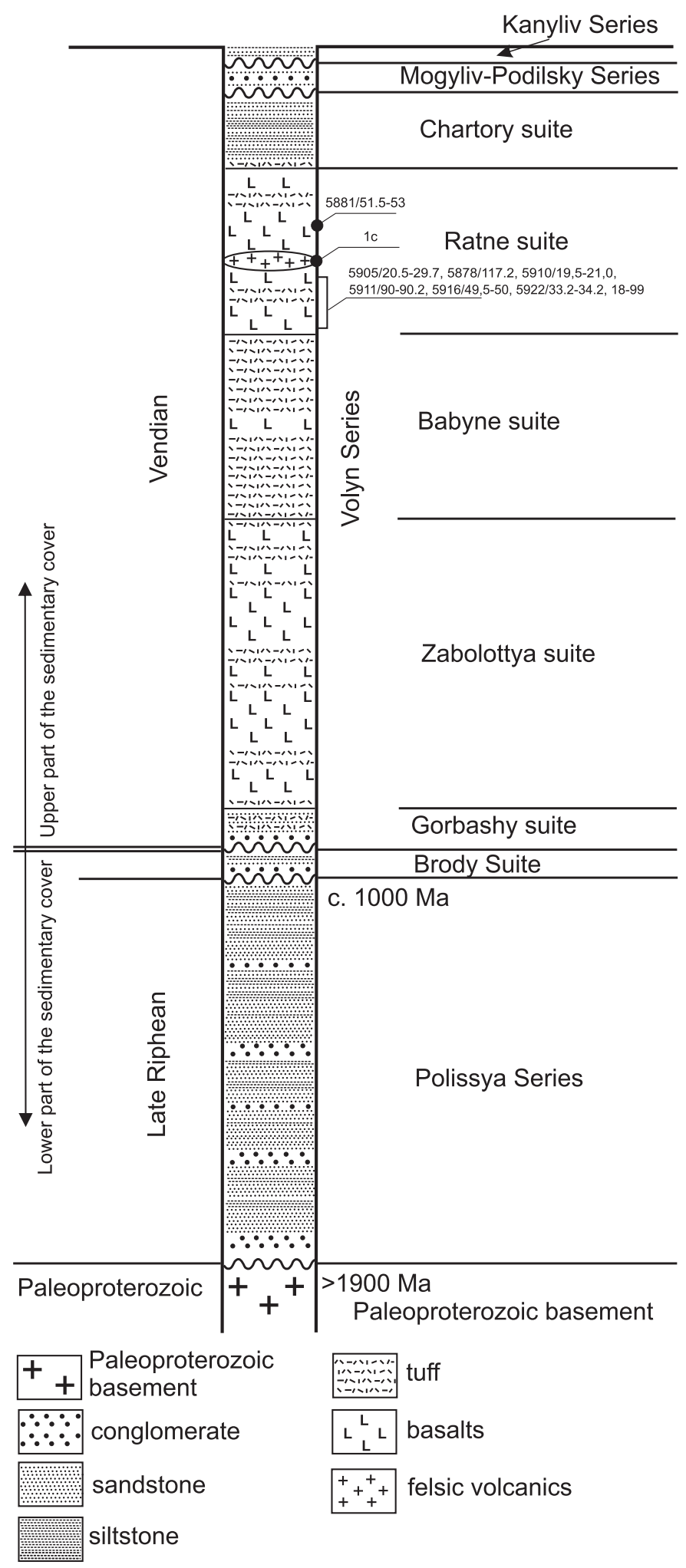

Fig. 3. Simplified stratigraphic column of the Late Proterozoic-Early Palaeozoic formations of the Volyno-Podolian monocline. Not to scale. Location of the zircon samples studied in this work is shown. Zircon samples 955/17, 955/14, 954-3, 60/1 and baddeleyite sample 68/147154 were taken from the dolerite intrusions (not shown on the column) that cut sediments of the Polissya Series. 
sequence rest upon the Polissya Series and Brody suite and in places directly overlies the crystalline basement (Figs. 1 and 3). The Volyn Series can be traced over a distance of $770 \mathrm{~km}$ from Bialystok in Poland to Chernivtsy in Ukraine. Its width exceeds $300 \mathrm{~km}$ in the central part while the maximum thickness (up to $400-600 \mathrm{~m}$ ) is confined to the axial part of the Volyn-Orsha depression. The Volyn Series can be further subdivided into a lowermost part (40-50 m), termed the Gorbashy suite, which is composed mainly of conglomerates and sandstones, while the main part of the Volyn Series consists of basic effusive and pyroclastic rocks, forming a flood basalt province. Thin picrite flows can be occasionally found among clastic sediments of the Gorbashy suite.

The volcanogenic sequence of the Volyn Series which constitutes the Volyn Large Igneous Province is subdivided into three parts in Ukraine (from bottom to top) called the Zabolottya, Babyne and Ratne suites (Birulyov 1968). These rocks are poorly exposed and mainly available from numerous drillings only few of which have penetrated the whole volcanogenic sequence. Tuffs and basalts of the uppermost Ratne suite crop out in several quarries and were extensively investigated. Effusive rocks of the lowermost Zabolottya suite are less abundant and found almost entirely within the Volyn-Orsha depression. They consist of one to eight basaltic flows with a subordinate $(<25 \%$ of the total suite thickness) amount of pyroclastic material. The maximal thickness of the suite reaches $166 \mathrm{~m}$ but is usually a few tens of metres. The Babyne suite is the most widely distributed and composed mainly of volcanoclastic sediments. In the flanks of the province, tuffs of the Babyne suite rest directly on the Polissya sediments and crystalline basement. The suite comprises layered, mainly fine- to medium-grained vitroclastic basaltic tuffs with abundant interlayers of fine-grained vitro-crystalloclastic and coarse lithoclastic tuffs. Tuffs are brown, reddish-brown and greenish-grey. Fine-grained tuffs usually appear as thin parallel-bedded rocks, whereas coarse-grained tuffs possess a faint cross-bedding. One to two basaltic flows occur in the central part of the Babyne suite, the thickness of which reaches $180 \mathrm{~m}$. In distal areas, pyroclastic rocks of the suite often contain a significant portion of terrigeneous material represented by interlayers of sandstones and tuffites. The Ratne suite is the uppermost one and is the best studied (Białowolska et al. 2002; Nosova et al. 2008; Shumlyanskyy 2008). Tuffs are rare while basaltic flows vary in thickness from 5-10 to 50-60 $\mathrm{m}$ and are separated from each other by volcanic breccias. Basaltic fragments are cemented either by fine ash or by aphanitic lava. There are up to ten basaltic flows and the total thickness of the suite can exceed $220 \mathrm{~m}$. Intermediate and felsic (andesite-dacite) rocks appear locally in the north-western part of the Volyn province known as the Brest depression in Belarus (Makhnatch 1968). The maximum thickness of the felsic rocks is $112 \mathrm{~m}$, but due to a small areal occurrence, they only constitute a few per cent of the total volume of the Volyn province.

Reddish sandstones, argillites and siltstones of the Chartory suite overlie locally outcropping volcanogenic rocks of the Volyn Series and contain a small amount of volcanoclastic material. The Chartory suite completes the "Volyn" cycle of the depression development. After its formation, a short break in sedimentation occurred during which both volcanic rocks of the Volyn Series and Palaeoproterozoic crystalline rocks of the Ukrainian shield experienced some weathering and erosion. In general, the Volyn Series is overlain by Early Palaeozoic continental sedi- ments that include deltaic river bed deposits that pass upwards into coastal and shallow marine sediments, in turn overlain by transgressive deep sea terrigeneous formations (Znamenskaya \& Chebanenko 1985).

\section{Geochemistry of Volyn flood basalts: a brief description}

A detailed geochemical description of the Volyn flood basalt sequence is beyond the scope of this article and will be reported elsewhere. Aspects of the geochemistry of the Volyn flood basalt and related rocks were reported by Bakun-Czubarow et al. (2002), Białowolska et al. (2002), Nosova et al. (2008), Shumlyanskyy (2008, 2012), Shumlyanskyy et al. (2011). In general, the Volyn province embraces the following rock types, from bottom to top: (1) locally distributed picrites among terrigeneous rocks of the Gorbashy suite; (2) olivine basalts of the Zabolottya suite; (3) low-Ti, high-Al basalts (one to two flows or possibly sheet intrusions) in the middle part of the Babyne suite; these are underlain and covered by thick tuff horizons; (4) low-Ti and low$\mathrm{Nb}$ tholeiite basalts of the lower part of the Ratne suite; (5) felsic volcanics, locally distributed in the northern Belarus; (6) high-Ti tholeiite basalts of the upper part of the Ratne suite that rest either on low-Ti tholeiite basalts or on felsic volcanics. High-Ti dolerite sills geochemically close to the high-Ti tholeiite basalts are rather common immediately beneath the Volyn flood basalt sequence where they cut terrigeneous sediments of the Polissya Series.

Chemical compositions of minerals and rocks vary regularly in the vertical section of the Volyn Series. In particular, calcic plagioclases (up to $\left.\mathrm{An}_{86}\right)$, magnesian orthopyroxene $\left(\mathrm{En}_{82} \mathrm{Fs}_{13} \mathrm{Wo}_{5}\right)$ and clinopyroxene $\left(\mathrm{En}_{59} \mathrm{Fs}_{9} \mathrm{Wo}_{32}\right)$ are characteristics for picrites. These rocks contain olivine phenocrysts while the opaques are represented by chromite. Upwards in the section, plagioclase becomes more sodic and pyroxenes more ferrous. Olivine is still present in the Babyne suite basalts but disappears in basalts of the Ratne suite. Plagioclase phenocrysts found in the Ratne suite basalts are very close in composition to plagioclases present in groundmass of picrites or Zabolottya suite basalts. Intrusive dolerites are very close in mineral chemistry to the Ratne suite basalts but contain olivine instead of orthopyroxene.

The whole-rock \#Mg, ranging between 69 and 73 in picrite, gradually decreases upwards and reaches 35-60 in high-Ti basalts of the Ratne suite and intrusive dolerites. REE abundances and degree of their fractionation gradually increase upwards in the section. A negative Eu anomaly is characteristic for picrites and for some of the Babyne suite basalts, while a weak positive $\mathrm{Eu}$ anomaly was found in low-Ti basalts of the Ratne suite and in dolerites. $\varepsilon \mathrm{Nd}$ in rocks gradually increases upwards from -12 in picrites to between -1 and -6 in high-Ti Ratne basalts and reaches values of -1 to -3 in dolerites.

\section{Previous geochronological data on Volyn flood basalts}

The radiometric age of the Volyn flood basalts is poorly constrained, although on the basis of the described above stratigraphical evidence, this is attributed to the Early Vendian (Kruglov \& 
Tsypko 1988). The basalts of the Ratne suite were extensively investigated using the K-Ar method (Semenenko 1975; Starytskyy 1981), but results are not conclusive. Ages generally fall within the interval 650-540 Ma, with some as young as $180 \mathrm{Ma}$, indicating recent Ar loss. Postnikova (1977) reported K-Ar ages of the Volyn flood basalt province between 690 and $560 \mathrm{Ma}$. Recently, Elming et al. (2007) carried out ${ }^{40} \mathrm{Ar} /{ }^{39} \mathrm{Ar}$ whole-rock age determinations on a set of the Ratne basalt samples. In general, their results fall into two groups. The first group includes four samples with ages in the range of 590-560 Ma and is indicating some excess Ar. The second group embraces samples with plateau ages varying from 393 to $369 \mathrm{Ma}$ that broadly correspond to the time of formation of the Devonian Prypyat aulacogen (Fig. 1).

Compston et al. (1995) investigated zircons from the uppermost tuff bed sampled from a drill core in eastern Poland (Fig. 1), believed to represent the last eruptive event related to the Volyn volcanism. Their preferred U-Pb age (SHRIMP method) was $551 \pm 4 \mathrm{Ma}$, with a few inherited grains $(558 \pm 8 \mathrm{Ma}$ and $635 \pm 10 \mathrm{Ma})$.

Shumlyanskyy \& Derevska (2001) used the Rb-Sr isochron method on three samples of basalt and one sample of footwall lava breccia taken from the same flow in the basal part of the Ratne suite. A regression line drawn through all four samples yielded $552 \pm 59$ Ma which was interpreted as the age of hydrothermal alteration. In fact, this regression line is essentially controlled by one point, a lava breccia that is heavily altered.

It must be noted that the whole Volyn continental flood basalt sequence, including dolerite intrusions, was subjected to a pervasive hydrothermal alteration that includes both massive percolation of fluids into rocks and more channelled veins filled with secondary minerals that include among others analcite, zeolites, silica minerals, chlorite, calcite and native copper. The timing of this alteration is not well established. The general idea is that it developed immediately after eruption due to penetration of volcanic-derived fluids into still hot rocks. However, a developed horizontal zonation of secondary mineral assemblages indicates alteration during the basinal stage of evolution, at which the flood basalt sequence was buried under thick sedimentary cover and subjected to influence of the heated basin waters. In this case, alteration may have occurred several tens of millions of years after eruption. Finally, this area was affected by severe heating during the Devonian development of the Prypyat branch of the Prypyat-Dnieper-Donets palaeorift. Some mineral assemblages may have developed in response to this process.

\section{Analytical methods and sampling}

Our primary intention was to refine the time of eruption of mafic and felsic rocks of the Volyn province using U-Pb SIMS technique on zircons and TIMS multigrain dating on baddeleyite. Our samples belong to the basalts that represent the Ratne suite (Fig. 1). In total, zircons were separated from 8 basalt samples (Table 1) of which one represents a high-Ti (upper part of the suite), while the rest of samples represent low-Ti (lower part of the suite) varieties of the Ratne basalts. In addition, we analysed zircons separated from three samples and baddeleyites isolated from one sample that represent dolerite (sill-like) bodies found among Polissya sandstones beneath the Volyn Series (Tables 2 and 3 ). In all cases, zircon yield was very low, generally only a few grains were recovered from samples varying in weight from few to over $100 \mathrm{~kg}$. Most of them were dated in this study.

A rhyolitic dacite flow, recovered from a drill hole in Belarus (1c at 1108-1157 $\mathrm{m}$ depth), that represents a rare suite of felsic rocks locally present in the Brest depression and stratigraphically occurring between the low- and high-Ti Ratne basalts was also studied (Table 4). This drill core specimen yielded much more zircons - over 100 grains, some of which were analysed in course of this study.

Individual zircon grains separated from basaltic and dolerite samples were analysed at the Swedish Museum of Natural History. Such crystals were mounted in epoxy along with the 91500 standard zircon (Wiedenbeck et al. 1995) and then sectioned and polished to approximately half of their thickness. Polished grains were investigated with a Hitachi SEM equipped with a CL detector. Obtained images were used for choosing areas suitable for $\mathrm{U}-\mathrm{Pb}$ dating. U-Th-Pb geochronological data were obtained using the Cameca 1270 ion microprobe at the NORDSIM facility. The determinations of the $\mathrm{Pb} / \mathrm{U}$ ratio, element concentration and calibration of the $\mathrm{Th} / \mathrm{U}$ ratio were performed relative to the Geostandard zircon 91500. The analytical method follows that described by Whitehouse \& Kamber (2005). The common lead correction, when needed, was made using the measured ${ }^{204} \mathrm{~Pb}$ signal and modern $\mathrm{Pb}$ isotope composition (Stacey \& Kramers 1975). Data reduction employed Excel macros developed by M.J. Whitehouse.

The $\mathrm{U}-\mathrm{Pb}$ analysis of zircons separated from the rhyolitic dacite was conducted using the ion microprobe SHRIMP-II in the Center for Isotopic Studies (VSEGEI, St. Petersburg, Russia) following routines described in Rodionov et al. (2012). The $\mathrm{Pb} / \mathrm{U}$ values were normalized to the ratio of 0.0665 for ${ }^{206} \mathrm{~Pb} /{ }^{238} \mathrm{U}$ in the zircon standard TEMORA, which corresponds to an age of $416.7 \pm 1.30 \mathrm{Ma}(2 \sigma)($ Black et al. 2003).

The baddeleyite-bearing sample 68/147-154 was processed at the Department of Geology at Lund University, following the standard procedures of Söderlund \& Johansson (2002). Extracted baddeleyite grains are up to $50 \mu \mathrm{m}$ in length and moderately brown. Approximately 40 grains in total were recovered from ca $150 \mathrm{~g}$ of sample. A total of 5-10 grains were combined in each fraction and the grains were transferred into a Teflon dissolution capsule using a handmade micropipette. The grains were washed in several steps, including a wash in $3 \mathrm{~N} \mathrm{HNO}$ on hotplate for ca. $30 \mathrm{~min}$. Each fraction was spiked with a ${ }^{205} \mathrm{~Pb}^{233-236} \mathrm{U}$ isotopic tracer solution. The grains were dissolved in a 10:1 $\mathrm{HF}: \mathrm{HNO}_{3}$ at $190{ }^{\circ} \mathrm{C}$ for 3 days and then evaporated on a hot plate at $100{ }^{\circ} \mathrm{C}$.

The fractions were dissolved in 10 drops of $6 \mathrm{~N} \mathrm{HCl}$ and 1 drop of $0.25 \mathrm{~N} \mathrm{H}_{3} \mathrm{PO}_{4}$ acid and then dried down on a hot plate at $90{ }^{\circ} \mathrm{C}$. The sample was re-dissolved in $1.8 \mu \mathrm{l}$ of silica gel and loaded on outgassed Re single filaments. Uranium and $\mathrm{Pb}$ isotopic ratios were measured on a TIMS Finnigan Triton mass spectrometer at the Museum of Natural History in Stockholm, Sweden. The $\mathrm{U}$ and $\mathrm{Pb}$ isotopic composition were analysed using a Secondary Electron Multiplier (SEM) equipped with RPQ in the peak-switching mode. The procedural total blank was estimated to be $0.5 \mathrm{pg}$ for $\mathrm{Pb}$ and $0.05 \mathrm{pg}$ for $\mathrm{U}$. The decay constants are those from Jaffrey et al. (1971), and the initial common lead composition was based on the terrestrial model of Stacey \& Kramers (1975) at the age of the sample. All age errors are given at the $95 \%$ confidence level. U-Pb concordia plots and age calculations were made using ISOPLOT version 3.75 of Ludwig (2012). 


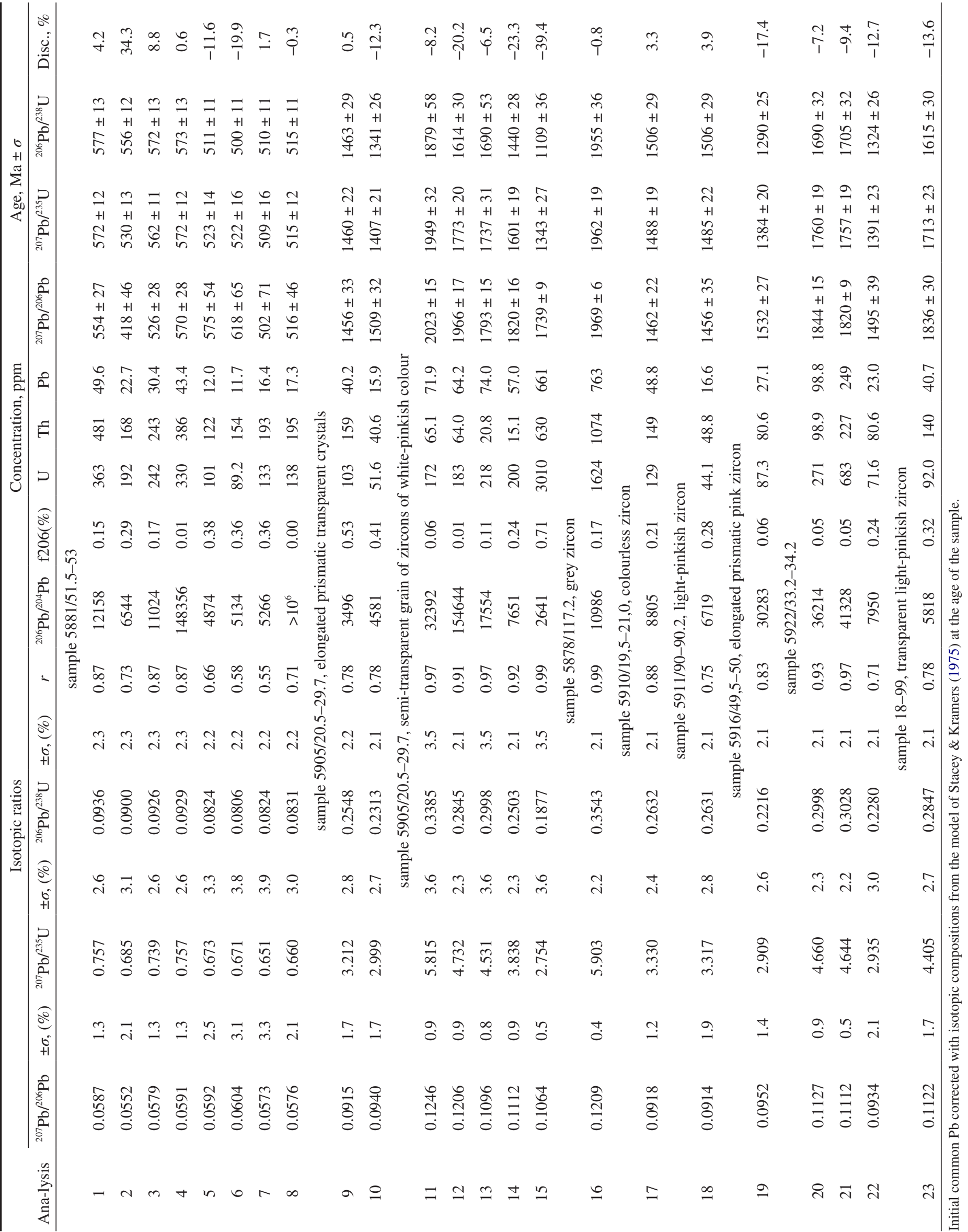



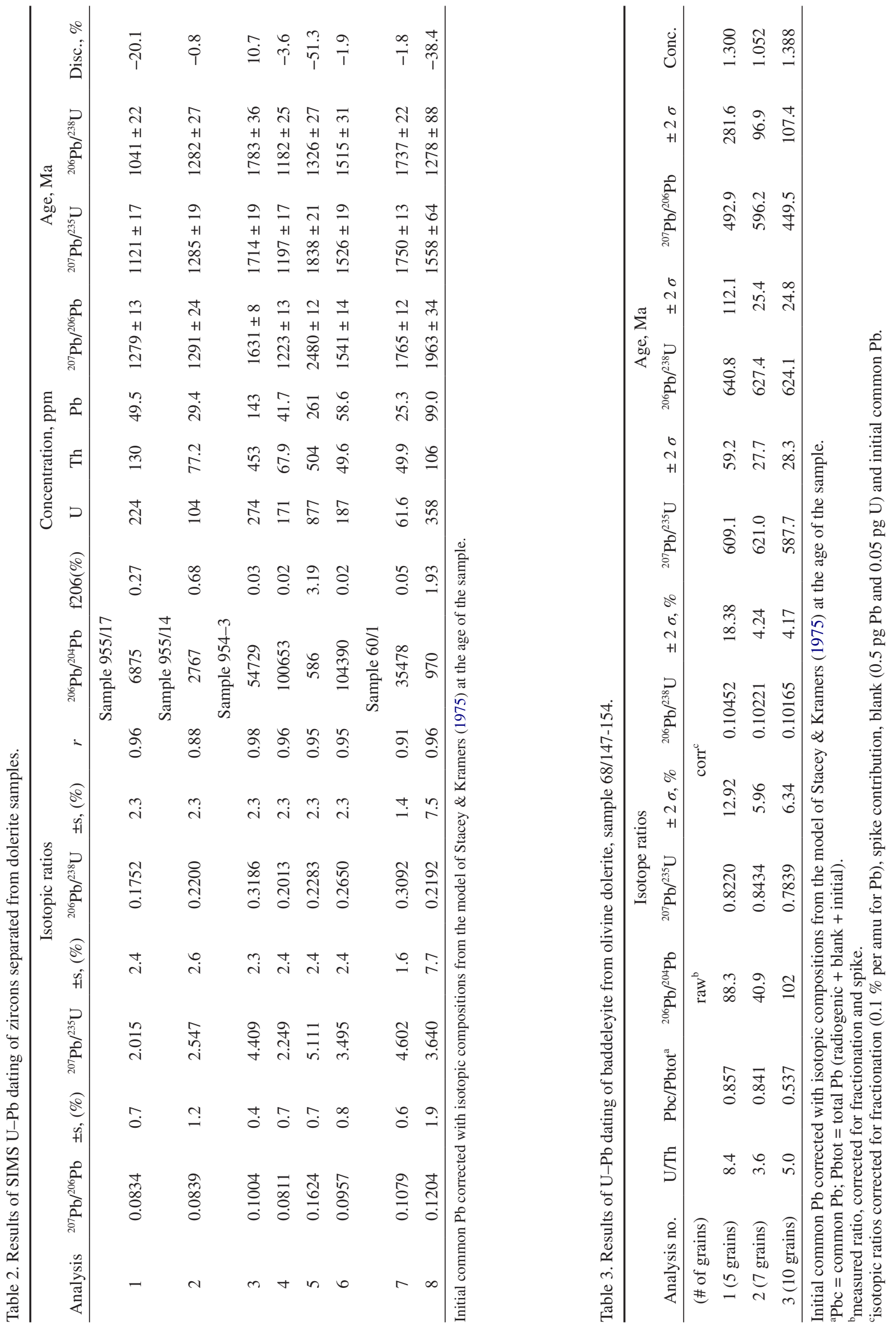
Table 4. Results of SIMS U-Pb dating of zircons separated from a rhyolitic dacite, sample 1c (Skveriki drill hole).

\begin{tabular}{|c|c|c|c|c|c|c|c|c|c|c|c|c|}
\hline \multirow[b]{2}{*}{ Analysis } & \multicolumn{6}{|c|}{ Isotopic ratios } & & \multicolumn{3}{|c|}{ Concentrations, ppm } & \multicolumn{2}{|c|}{ Age, Ma } \\
\hline & ${ }^{207} \mathrm{~Pb} /{ }^{206} \mathrm{~Pb}$ & $\pm \mathrm{s},(\%)$ & ${ }^{207} \mathrm{~Pb} /{ }^{235} \mathrm{U}$ & $\pm \mathrm{s},(\%)$ & ${ }^{206} \mathrm{~Pb} /{ }^{238} \mathrm{U}$ & $\pm \mathrm{s},(\%)$ & $\mathrm{r}$ & $\mathrm{U}$ & Th & $\mathrm{Pb}$ & ${ }^{207} \mathrm{~Pb} /{ }^{206} \mathrm{~Pb}$ & ${ }^{206} \mathrm{~Pb} /{ }^{238} \mathrm{U}$ \\
\hline $1 \mathrm{C} .3 .1^{*}$ & 0.0582 & 1.4 & 0.700 & 2.1 & 0.0873 & 1.6 & 0.75 & 665 & 314 & 49.9 & $539 \pm 8$ & $540 \pm 8$ \\
\hline 1C.3.1 & 0.0559 & 5.4 & 0.699 & 5.7 & 0.0906 & 1.9 & 0.33 & 88 & 102 & 6.9 & $448 \pm 24$ & $559 \pm 10$ \\
\hline 1C.10.1 & 0.0568 & 9.4 & 0.722 & 9.7 & 0.0923 & 2.1 & 0.22 & 45 & 47 & 3.6 & $484 \pm 45$ & $569 \pm 12$ \\
\hline 1C.7.1 & 0.0542 & 13.0 & 0.693 & 13.0 & 0.0927 & 2.4 & 0.19 & 44 & 46 & 3.6 & $380 \pm 49$ & $571 \pm 13$ \\
\hline 1C.8.1 & 0.0572 & 9.3 & 0.734 & 9.5 & 0.0929 & 2.0 & 0.21 & 66 & 59 & 5.3 & $500 \pm 47$ & $573 \pm 11$ \\
\hline 1C.5.1 & 0.1597 & 1.6 & 5.960 & 2.3 & 0.2705 & 1.5 & 0.68 & 949 & 1118 & 221 & $2453 \pm 28$ & $1543 \pm 21$ \\
\hline 1C.11.1 & 0.1058 & 2.3 & 4.390 & 3.0 & 0.3006 & 1.9 & 0.65 & 56 & 6 & 14.5 & $1729 \pm 42$ & $1694 \pm 29$ \\
\hline 1C.1.1 & 0.1186 & 1.1 & 5.007 & 2.0 & 0.3063 & 1.6 & 0.82 & 170 & 99 & 44.7 & $1934 \pm 20$ & $1723 \pm 25$ \\
\hline 1C.2.1 & 0.1125 & 0.8 & 4.859 & 1.8 & 0.3133 & 1.6 & 0.90 & 611 & 467 & 164 & $1840 \pm 14$ & $1757 \pm 25$ \\
\hline 1C.5.1* & 0.1772 & 0.5 & 7.680 & 1.6 & 0.3141 & 1.5 & 0.95 & 531 & 605 & 144 & $2627 \pm 9$ & $1761 \pm 24$ \\
\hline 1C.4.1 & 0.1145 & 0.9 & 5.241 & 1.9 & 0.3320 & 1.6 & 0.88 & 350 & 268 & 100 & $1872 \pm 16$ & $1848 \pm 26$ \\
\hline 1C.6.1 & 0.1809 & 0.9 & 12.000 & 1.8 & 0.4812 & 1.5 & 0.87 & 467 & 197 & 193 & $2661 \pm 14$ & $2532 \pm 32$ \\
\hline
\end{tabular}
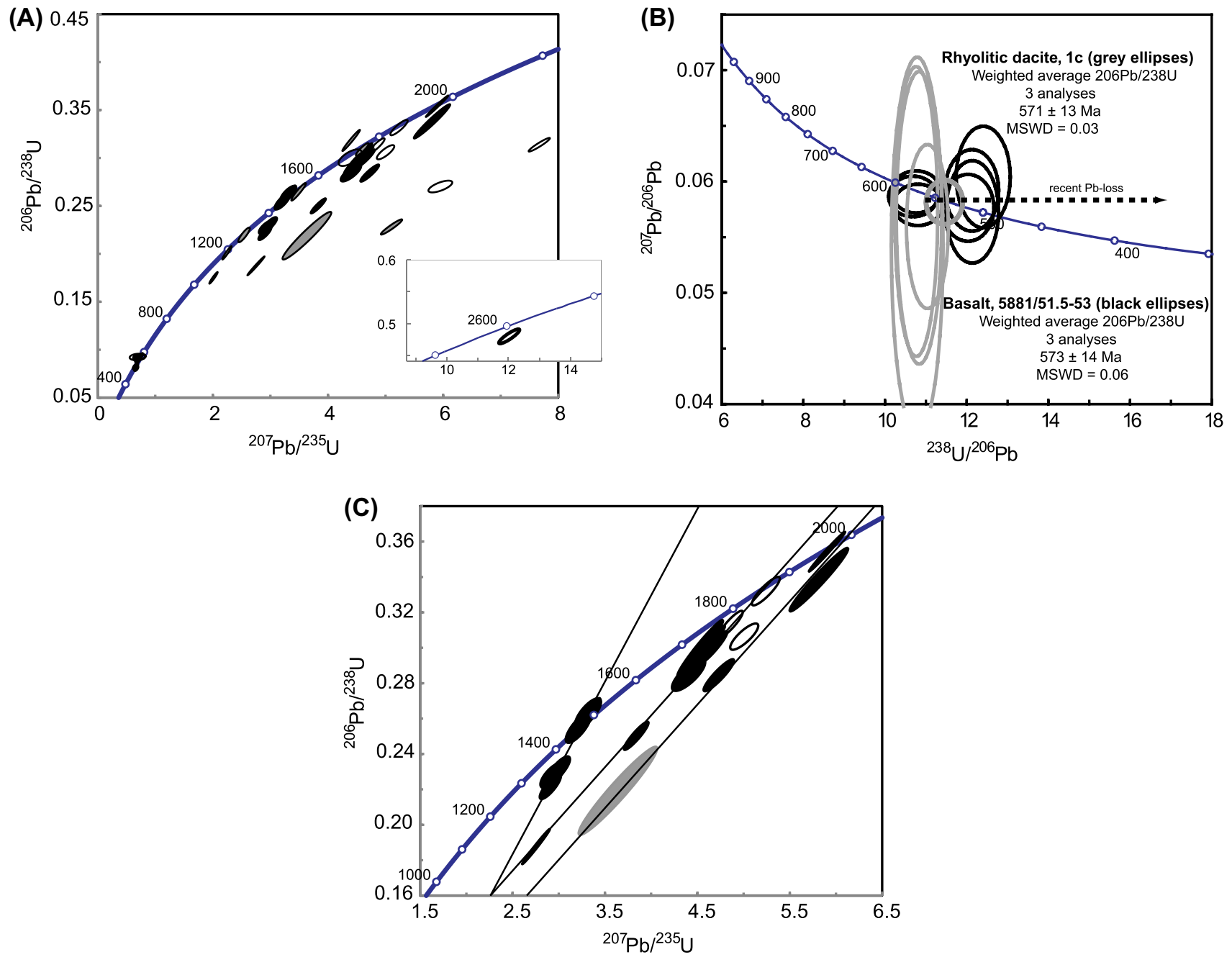

Fig. 4. Results of U-Pb ion probe analyses of zircons separated from the rocks of the Volyn flood basalt province. A. Concordia diagram giving an overview of the obtained results. Black filed symbols signify zircons from basalts, grey symbols are zircons from dolerites, and black unfilled symbols are zircons from a rhyolitic dacite. B. Tera-Wasserburg diagram showing data for zircons from the high-Ti basalt sample 5881/61, 5-63 (black symbols), and for zircons from the rhyolitic dacite sample 1c (grey symbols). C. Detailed concordia diagram for zircons formed at c. $1.5,1.8$ and $2.0 \mathrm{Ga}$ (symbols as in $\mathbf{A}$ ). 


\section{Isotope age data and zircon characteristics}

\section{1. $U-P b$ dating of zircons isolated from basaltic samples}

The zircons separated from Ratne basalts can be divided into four principle groups according to their ${ }^{207} \mathrm{~Pb} /{ }^{206} \mathrm{~Pb}$ dates, suggesting crystallization at about 550-570, 1470, 1820 and $2050 \mathrm{Ma}$ (Fig. $4(\mathrm{~A}))$.

7.1.1. High-Ti basalt. All the zircons yielding a Vendian age (Fig. 4(B)) were from the high-Ti basalt sampled in drill hole 5881. These zircons vary in size from $70 \times 120-150$ to $150 \times 350 \mu \mathrm{m}$ and occur as pink (sometimes almost colourless), euhedral, prismatic grains with very well-developed prism facets and reduced pyramidal ones. The latter can be entirely lacking. All of the studied crystals contain small rounded inclusions and display oscillatory rhythmical zoning (Fig. 5). Small cores are present in some grains. Sector zoning is a very characteristic feature for some of the crystals. Eight $\mathrm{U}-\mathrm{Pb}$ analyses were performed on seven grains (Table 1, Figs. 4(B) and 5), and six of these analyses yielded concordant or nearly concordant results. Unfortunately, obtained results do not allow unequivocal interpretation of the age of crystallization of this rock as a regression comprising four of the analyses yields an upper intercept age of $577 \pm 22 \mathrm{Ma}$, whereas a regression constructed for the rest four analyses indicates an age of $513 \pm 15 \mathrm{Ma}$. We interpret these younger ages as those that have suffered from the recent $\mathrm{Pb}$-loss (Fig. 4(B)). The weighted average ${ }^{206} \mathrm{~Pb} /{ }^{238} \mathrm{U}$ age for the three older crystals is $573 \pm 14 \mathrm{Ma}$ (MSWD $=0.06$ ). We accept this age as the most probable time of crystallization of the high-Ti basalt.

7.1.2. Low-Ti basalts. Zircons separated from seven low-Ti basalt samples yielded ages much older than c. $570 \mathrm{Ma}$ (Table 1), which clearly must represent the presence of zircon xenocrysts in these samples. Several analyses group at c. $1470 \mathrm{Ma}$ (Fig. 4(C)). These zircons possess an elongated prismatic habit and rather poorly developed pyramid facets. Crystal apices are often rounded, probably indicating some resorption. Mineral inclusions are common. Zoning is prism-parallel or concentric with distinctive cores (cores were not analysed). All analysed crystals are characterized by rather low and variable concentrations of $\mathrm{U}$ (44-129 ppm) and Th (49-159 ppm). The analysed points may be approximated by a regression line that intersects the concordia at $1467 \pm 23$ Ma with a lower intercept at $-812 \pm 890 \mathrm{Ma}$. There are no known magmatic or metamorphic rocks of this age directly underlying the Volyn continental flood basalt province. However, rocks of such age are common in north-eastern Poland and Lithuania where they belong to the Mazury anorthositemangerite-charnokite-granite complex (Skridlaite et al. 2006; Wiszniewska et al. 2007).

Another group of morphologically distinct zircons was formed at about $1820 \mathrm{Ma}$. These appear as elongated prismatic grains with well-developed prismatic facets and poor pyramids.

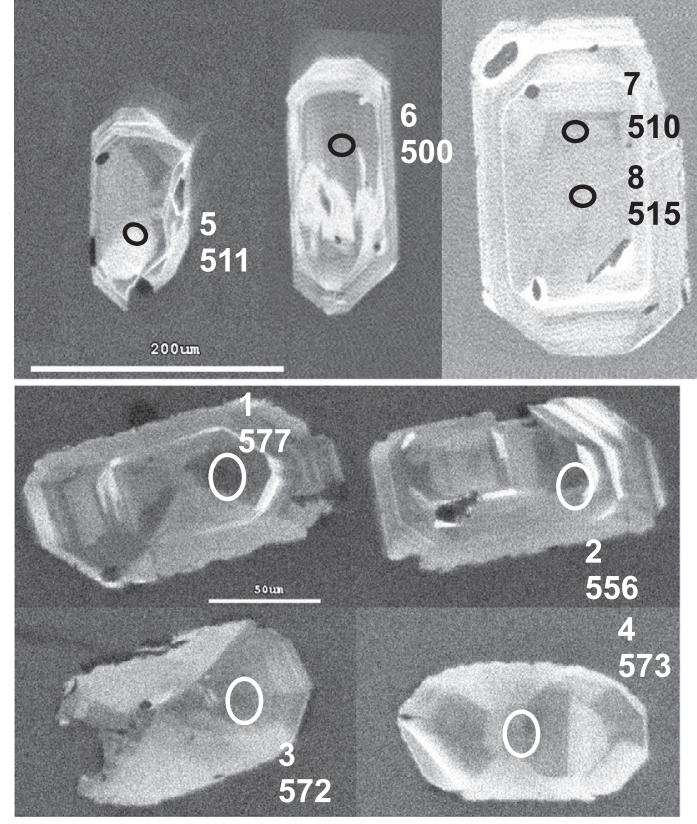

Fig. 5. A selection of CL images of zircons separated from the high-Ti basalt sample 5881/61, 5-63. Numbers correspond to analyse \# in Table 1 and ${ }^{206} \mathrm{~Pb} /{ }^{238} \mathrm{U}$ age in $\mathrm{Ma}$.

Distinct cores and complex prismatic zoning can often be seen. Crystals are grey or very light pinkish. In the concordia diagram, the age of rims of this group can be approximated by a discordia indicating an upper intercept age at $1819 \pm 51 \mathrm{Ma}$, with a lower intercept at ca. 0 Ma (Fig. 4(C)).

Two zircon grains separated from the low-Ti basalts (samples 5905/20.5-29.7 and 5878/117.2) of the Volyn province yielded even older ages (Fig. 4(A)). One of them is translucent, white-pinkish, clearly zoned and yielded a ${ }^{207} \mathrm{~Pb} /{ }^{206} \mathrm{~Pb}$ age of $2023 \pm 15 \mathrm{Ma}$ for the core portion, while the mantle formed at $1793 \pm 15 \mathrm{Ma}$. The second crystal is grey, euhedral, slightly zoned with a large homogeneous core and a thin mantle. In contrast to the external habit, the core is rounded. In spite of very high concentrations of $\mathrm{U}(1624 \mathrm{ppm})$, Th (1074 ppm) and $\mathrm{Pb}(763 \mathrm{ppm})$, the core yielded a concordant $\left({ }^{207} \mathrm{~Pb} /{ }^{206} \mathrm{~Pb}\right)$ age at $1969 \pm 6$ Ma.

\section{2. $U-P b$ dating of zircons isolated from dolerite samples}

Zircons were separated from four dolerite samples (60/1, 954$3,955 / 14$ and 955/17) that represent numerous sheet-like intrusive bodies located immediately beneath the Volyn flood basalt sequence. Zircons from dolerites are usually fine $(0.1-0.15 \mathrm{~mm}$ and less) and variable in terms of their external appearance and internal texture. Eight grains were analysed (Table 2); six of them yielded concordant to nearly concordant results and their approximate ${ }^{207} \mathrm{~Pb} /{ }^{206} \mathrm{~Pb}$ ages are as follows: $1.76,1.63,1.54$, 1.29 and $1.22 \mathrm{Ga}$. The two discordant analyses indicate even older ages, one of them possibly Archaean. 


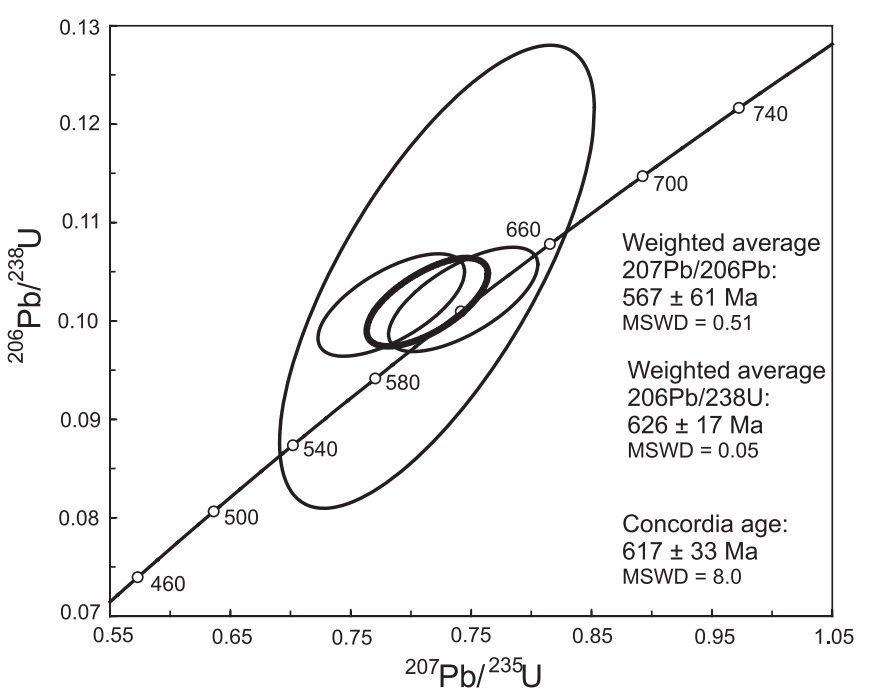

Fig. 6. Concordia diagram for baddeleyite from the olivine dolerite sample $68 / 147-154$.

\section{3. $U-P b$ dating of baddeleyite isolated from dolerite sample}

The three multigrain fractions of baddeleyite from sample 68/147-154 all yielded nearly concordant results (Table 3). Unfortunately, due to the small amount of material (low radiogenic/common lead ratios) and low signal intensities, the precision of measurements is poor. The ${ }^{207} \mathrm{~Pb} /{ }^{206} \mathrm{~Pb}$ weighted average is $567 \pm 61 \mathrm{Ma}(\mathrm{MSWD}=0.51)$, whereas the ${ }^{206} \mathrm{~Pb} /{ }^{238} \mathrm{U}$ weighted average is $626 \pm 17 \mathrm{Ma}$ (MSWD $=0.05$, Fig. 6).

\section{4. $U-P b$ dating of zircons isolated from a rhyolitic dacite}

A rather small sample ( $<3 \mathrm{~kg}$, sample 1c) yielded about 100 zircon grains which are variable with respect to appearance and age. According to their characteristics, grains were subdivided into four groups.

The first group comprises about $70 \%$ of all zircon grains that appear as prismatic colourless crystals with well-developed facets. These can be either homogeneous or contain poorly distinguishable cores. Some of them contain inclusions. Two morphological sub-groups of zircons of this type were recognized, and both groups display well-developed magmatic zoning (Fig. 7) and high $\mathrm{Th} / \mathrm{U}$ ratios (0.9-1.2), suggesting a magmatic origin: (a) fine $(0.1-0.2 \mathrm{~mm})$ short to moderately elongated prismatic grains with an aspect ratio of about 1.5. Pyramidal facets are well developed, edges are somewhat smoothed. Some of the grains are slightly resorbed; (b) larger $(0.2-0.4 \mathrm{~mm})$ elongated prismatic crystals with an aspect ratio up to 4. These are well-formed, with sharp edges and smooth facets, transparent, colourless, with rare inclusions. The weighted average ${ }^{206} \mathrm{~Pb} /{ }^{238} \mathrm{U}$ age for four of five analysed zircon grains from this group is $567 \pm 11 \mathrm{Ma}$; the fifth grain is somewhat younger with ${ }^{206} \mathrm{~Pb} /{ }^{238} \mathrm{U}=540 \pm 8 \mathrm{Ma}$ (Table 4).

The second main group of magmatic zircons embraces two morphological varieties which together represent up to $20 \%$ of the sample. The first variety includes large (up to $0.4 \mathrm{~mm}$ ) resorbed colourless, transparent crystals. CL imaging demonstrates
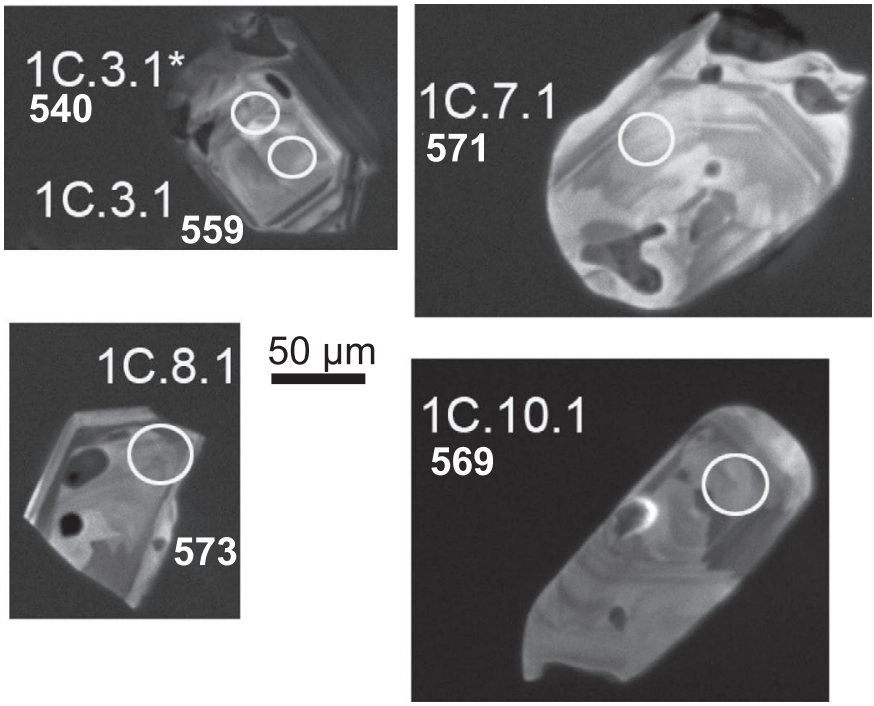

Fig. 7. A selection of CL images of the young igneous population of zircons separated from a rhyolitic dacite sample. Numbers correspond to analyse \# in Table 4 and ${ }^{206} \mathrm{~Pb} /{ }^{238} \mathrm{U}$ age in Ma.

the presence of inherited cores with rough sector zoning rimmed by mantles with fine oscillatory zoning. One analysis obtained for the core portion of grain 1C.1.1 is discordant (12\%); its ${ }^{207} \mathrm{~Pb} /{ }^{206} \mathrm{~Pb}$ age is $1934 \pm 20 \mathrm{Ma}$. Concentrations of $\mathrm{U}$ and $\mathrm{Th}$ in the core are moderate, while the $\mathrm{Th} / \mathrm{U}$ ratio is rather high (0.58). The second variety contains fine $(0.15-0.20 \mathrm{~mm})$ moderately elongated (aspect ratio ca. 2.0-2.5) semitransparent, yellowish-grey grains with smoothed edges and resorbed surfaces. These crystals possess a rough rhythmical zoning, high Th and $\mathrm{U}$ concentrations and a high $(0.77) \mathrm{Th} / \mathrm{U}$ ratio. Two analyses (1C.2.1 and 1C.4.1) are slightly discordant and yield an upper intercept age of $1853 \pm 20 \mathrm{Ma}$.

Zircons of a probable metamorphic origin constitute the third group and are represented by fine $(0.1-0.2 \mathrm{~mm})$ short-prismatic (isometric) grains with smoothed edges and perfect facets, transparent, pinky and visually homogeneous. CL imaging demonstrates a pattern which is typical for granulitic zircons: a contrast rough zoning with a wide, light-grey low-U mantle around a dark core. Both core and mantle are characterized by a low Th concentration and low $\mathrm{Th} / \mathrm{U}$ ratio $(0.10)$. The ${ }^{207} \mathrm{~Pb} /{ }^{206} \mathrm{~Pb}$ age of the single measured grain (1C.11.1) is $1729 \pm 42 \mathrm{Ma}$ (Fig. 4).

A few zircons of the fourth group occur as semi-transparent, brownish short-prismatic grains with well-defined edges and smooth facets. One of the analysed crystals (1C.6.1) yielded a near-concordant result with a ${ }^{207} \mathrm{~Pb} /{ }^{206} \mathrm{~Pb}$ age of $2661 \pm 14 \mathrm{Ma}$. Regression line constructed through this crystal and two other grains (1C.5.1* and 1C.5.1) intersects the concordia at $2664 \pm 32$ Ma.

\section{Discussion}

\subsection{Age of eruption}

The samples analysed in this study represent magmatic lithologies (basalts and dolerites) of the Volyn series in Ukraine as well as a rhyolitic dacite from Belarus occupying a nearly equal stratigraphical position, which is roughly constrained to the Late 


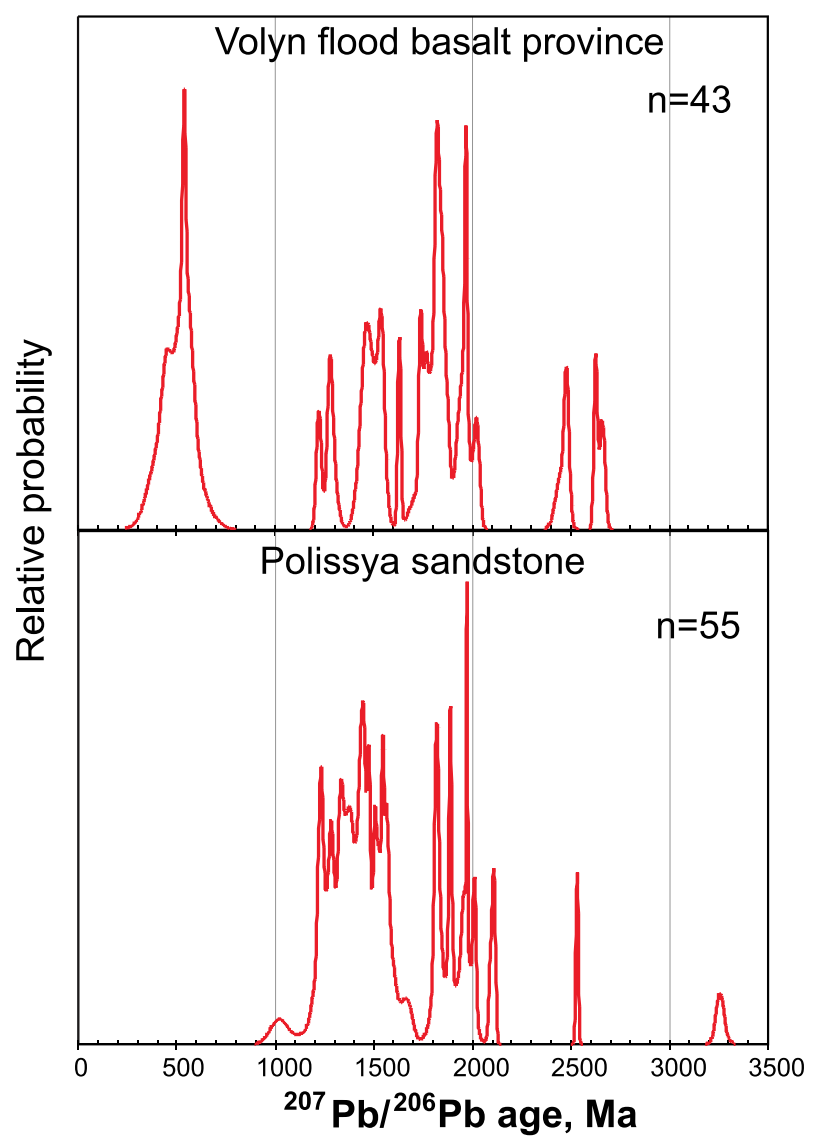

Fig. 8. Distribution of ${ }^{207} \mathrm{~Pb} /{ }^{206} \mathrm{~Pb}$ ages of zircons from rocks of the Volyn flood basalt province and from the Polissya sandstone. The raw data for the Polissya sandstone can be found in Shumlyanskyy et al. 2015.

Precambrian. However, a significant number of xenocrystic zircons with a wide range of Precambrian to Archaean ages were also found. Except for data from the high-Ti basalt, it appears that whenever several analyses are available from a single rock, such data reflect a number of different age populations. Obviously, inheritance is an important process to consider and it remains to be proven if any of the obtained younger ages corresponds to the time of rock eruption as there is no reliable way to distinguish xenocrystic from syn-genetic zircons. Hence, even youngest ages obtained for zircons in this study may belong to the xenocrysts.

Both the stratigraphic and tectonic position of the Volyn flood basalts clearly suggest an Ediacaran age of this magmatic province. Although less conclusive, available results from $\mathrm{K}-\mathrm{Ar}$, $\mathrm{Ar}-\mathrm{Ar}$ and $\mathrm{Rb}-\mathrm{Sr}$ dating are consistent with such an interpretation. The U-Pb zircon results obtained by Compston et al. (1995) for the uppermost tuffs $(551 \pm 4 \mathrm{Ma})$ in eastern Poland can be regarded as the most well-founded published ages. However, it is unclear to which degree this age is applicable to effusive rocks of other parts of the province. The studied rocks are unmetamorphosed, and although we have tried to sample as fresh rocks as possible, the lithologies have suffered post-crystallization hydrothermal alteration, and therefore, some disturbances of the $\mathrm{U}-\mathrm{Pb}$ system in zircon cannot be ruled out.

Our new $\mathrm{U}-\mathrm{Pb}$ data for young populations of zircons separated from the high-Ti basalt are somewhat confusing and apparently indicate different processes separated in time by some 60 Myrs. Such a long period of time is unlikely to reflect the duration of the outpouring of the sampled basaltic flow, and also greatly exceeds the duration of the typical igneous pulse ( 1-5 Myrs) that normally leads to the formation of the main portion of large igneous provinces (Bryan \& Ernst 2008). Of the two indicated ages, the c. 570 Ma zircons in basalt and rhyolitic dacite could be inherited, and in this case, the real age of eruption is represented by c. $510 \mathrm{Ma}$ zircons. However, a $510 \mathrm{Ma}$ age appears to be too young and contradicts the stratigraphic and tectonic evidence which clearly argue for a Late Precambrian age. Although it cannot be completely ruled out that zircons yielding the $570 \mathrm{Ma}$ age also are inherited, we believe that the fact that these originate from the least contaminated variety of the Volynian basalt (the high-Ti basalt) would argue for that assimilation of older crustal components is minimal or non-existing. Moreover, zircons, seemingly of a magmatic origin in the rhyolitic dacite, support that magmatism occurred in the 560-570 Ma interval. Thus, our preferred interpretation is that a $\sim 570 \mathrm{Ma}$ age represents the time of eruption of both high-Ti basalts and rhyolitic dacite. Following this, 510 Ma old zircons in the basalt probably represent a post-effusive stage of hydrothermal alteration, although no obvious support for this assumption is given by CL or morphological evidence.

Baddeleyite, unlike zircon, cannot be of xenocrystic or metamorphic origins (unless extreme conditions) why baddeleyite is often preferred over zircon for dating the crystallization of silica-undersaturated rocks. Unfortunately, the three analysed baddeleyite fractions do not allow for a definite interpretation of the age of sample $68 / 147-154$. The ${ }^{207} \mathrm{~Pb} /{ }^{206} \mathrm{~Pb}$ weighted average age of $567 \pm 61 \mathrm{Ma}$ is close to the zircon ages dating the time of eruption of basalts and felsic volcanites. However, the ${ }^{206} \mathrm{~Pb} /{ }^{238} \mathrm{U}$ weighted average of $626 \pm 17 \mathrm{Ma}$ is a more precise estimate. Both estimates provide acceptable MSWD values (below 1) and are marginally overlapping. We conclude that this sample must have crystallized roughly at $600 \mathrm{Ma}$ and that additional analyses, or datings of samples with a higher amount of baddeleyite from structurally coeval units, are required to better constrain the crystallization age. Further efforts to date other basaltic and dolerite samples and alteration mineral parageneses are required for a more thorough understanding of age relationships and of evolution of this province as a whole.

\subsection{Possible sources of old xenocrystic zircons}

As has been noted above, zircons from rocks of the Volyn flood basalt province can be divided into several groups according to their ${ }^{207} \mathrm{~Pb} /{ }^{206} \mathrm{~Pb}$ ages (Fig. 8). The zircon population yielding ca. $570 \mathrm{Ma}$ is likely to represent the age of the eruption. Thus, the fact that much older zircons are present in the Volyn province suggests that alien crystals were inherited from the source region during magma-forming process or assimilated from the wall rocks during magma ascent.

Although data are relatively few and have yielded scattered ages, it is nevertheless possible to discuss potential sources for xenocrystic zircons. The thick sedimentary sequence of the Polissya Series that represents a huge reservoir of zircons must be considered as a possible source of detrital zircons that can be captured by the mafic magma during its ascent to the surface. However, we consider such a scenario as less likely. Polissya sediments are rather loose rocks that were probably penetrated by 
ascending magmas quite quickly. Tentatively, on the other hand, their loose nature would favour a tendency for being captured and assimilated by the melts. However, Polissya sands contain up to $80-85 \%$ of $\mathrm{SiO}_{2}$ but silica enrichment has never been noted in the studied basalts which would argue against such a hypothesis. Moreover, the distribution of ages of zircons separated from the Polissya sandstones (Shumlyanskyy et al. 2015) is somewhat different from that typical for the Volyn continental flood basalts. For instance, Polissya rocks contain predominantly zircons of two age intervals - 1200-1600 and 1800-2000 Ma. Although there are distinct ${ }^{207} \mathrm{~Pb} /{ }^{206} \mathrm{~Pb}$ peaks at 1470 and $1820 \mathrm{Ma}$ in our analytical data, the c. $1620 \mathrm{Ma}$ peak is not characteristic for the sandstones (Fig. 8). Moreover, zircons aged between 1450 and $1200 \mathrm{Ma}$ are rare in the Volyn basalts but are very abundant in the Polissya sediments.

If the Polissya sediments constitute a less likely source for old zircons in the studied rocks, it follows that more deep-seated rocks supplied at least the vast majority of xenocrystic zircons. For instance, the older groups (ca. 1820 and $2050 \mathrm{Ma}$ ) of zircons may have been extracted from basement rocks that immediately underlie the Volyn province. Zircon ages at ca. $1820 \mathrm{Ma}$ correspond roughly to the time of formation of the Baltic-Belarus granulite belt and the collision of Sarmatia and Fennoscandia (Bogdanova et al. 2001; Claesson et al. 2001; Elming et al. 2010), while a $2050 \mathrm{Ma}$ age corresponds to the time when a major part of the Zhytomyr Complex granites was formed (Scherbak et al. 2008). However, a significant portion of the analysed zircons is much younger (ca. $1470 \mathrm{Ma}$ ). Appropriate rocks with ages $\leq 1500 \mathrm{Ma}$ are absent beneath the Volyn flood basalt province; however, such rocks are widely distributed north-westwards of the study area where these are represented by anorthosite-mangerite-charnokite-granite complexes, e.g. the 1.45-1.54 Ga old Mazury complex, see Fig. 2 (Skridlaite et al. 2006; Wiszniewska et al. 2007).

Yet another possibility is that xenocrystic zircons were derived from the Amazonia craton that in the Neoproterozoic time was conjuncted to Baltica across the TESZ and was rifted away during the Vendian (see below). An overview of the ages obtained for the south-western part of the Amazonia (Teixeira et al. 2015) clearly indicates that Amazonia could represent an important source of Neoproterozoic zircons, both for the Polissya Series sediments and for the Volyn flood basalts. However, as the exact position of the Amazonia relative to Baltica remains unknown this complicates an assessment about the possible role of Amazonia as a source of detrital (and xenocrystic) zircons found in the western part of the East European craton.

\subsection{Volyn flood basalt province in the context of Rodinia break-up}

There is a general consensus that Baltica existed as a part of the supercontinent known as Rodinia in the Late Proterozoic times. A wide range of reconstructions of the position of Baltica in relation to neighbouring continents, Laurentia and Amazonia, has been proposed. These include the work presented by $\mathrm{Li}$ et al. (2008) and Johansson (2009), in which the western margin of Baltica is located in front of Amazonia. A model for the breakup of these three continental masses was presented by Bingen et al. (1998) who considered a two-stage separation of (1) Baltica from Laurentia at 615-590 Ma and (2) break-up of all three continental masses at ca. 565-550 Ma.
Relevant ages to consider in this context include precise U$\mathrm{Pb}$ dates of baddeleyite separated from the Egersund dykes in Norway, located along the TESZ, yielded an age of $616 \pm 3 \mathrm{Ma}$ (Bingen et al. 1998), while the zircon age for the Sarek Dyke Swarm, northern Swedish Caledonides is $608 \pm 1$ Ma (Svenningsen 2001). In general, the majority of dates obtained by different methods (U-Pb of zircon and baddeleyite; whole-rock $\mathrm{Sm}-\mathrm{Nd}$ and $\mathrm{Rb}-\mathrm{Sr}$ isochrones) for mafic intrusions of the Baltoscandian margin fall into the interval 615-590 Ma (Andréasson et al. 1998; Bingen et al. 1998; Svenningsen 2001).

The emplacement of the Egersund and Sarek dykes closely corresponds to the ages of the Long Range swarm of Labrador that was formed at $615 \pm 2 \mathrm{Ma}$ (Kamo et al. 1989). Puffer (2002) considered a large body of dates related to mafic intrusions of the eastern Laurentia and divided the occurrences of mafic magmatism in this area into two groups: (1) the Mid-Vendian flood basalt group that was formed between 615 and $564 \mathrm{Ma}$ and (2) the Late-Vendian (LOIB) group formed between 554 and $550 \mathrm{Ma}$. The latter group is particularly well-defined and embraces 13 occurrences of mafic volcanism. While the Mid-Vendian group of Puffer (2002), in general, corresponds to the first stage of separation of Baltica from Laurentia defined by Bingen et al. (1998), the Late-Vendian group is synchronous with the final break-up of the three continental masses. These circumstances suggest that the eastern Laurentia Late-Vendian group of Puffer (2002) was related to the ocean opening between Laurentia and Amazonia.

It has been repeatedly shown that the break-up of the Rodinia supercontinent was a complex and prolonged process that lasted about 275 Myrs, from 825 to $550 \mathrm{Ma}$ (see Li et al. 2008, and references therein). The above given examples of palaeotectonic reconstructions of the Baltica-Laurentia-Amazonia configuration allow the recognition of the three arms of the rift system that led to the continental break-up. From geochronological data, it is evident that one of the arms was active at 615-590 Ma (and probably also somewhat later) and connected with the formation of the Iapetus Ocean. The formation of the Egersund dykes $(616 \pm 3 \mathrm{Ma})$ during this time interval probably signifies the initiation of the separation of Baltica and Amazonia. Two other arms that separated Amazonia from both Baltica and Fennoscandia, as evident from our new data, were active at c. 620-570 Ma, i.e. simultaneously with the separation of Baltica and Amazonia.

\section{Conclusions}

The Volyn flood basalt province occurs on the western margin of the East European platform and is clearly confined to the TESZ. Volcanogenic rocks of the province rest upon Neoproterozoic sediments or directly on the Palaeoproterozoic basement that in this area is represented by a transition zone between two segments of the East European craton - Sarmatia and Fennoscandia. Volyn flood basalts, in turn, are overlain by Late Vendian and Early Palaeozoic sediments that accumulated in a regime of a subsided passive continental margin.

Ion microprobe dating was carried out on texturally quite complex zircons separated from basaltic, doleritic and rhyolitic dacite samples. Magmatic zircons separated from one high-Ti basalt sample yielded an age of $573 \pm 14 \mathrm{Ma}$, whereas grains isolated from a rhyolitic dacite yielded $571 \pm 13 \mathrm{Ma}$. Baddeleyite from the olivine dolerite sample gave an older ${ }^{206} \mathrm{~Pb} /{ }^{38} \mathrm{U}$ age of $626 \pm 17 \mathrm{Ma}$, whereas the ${ }^{207} \mathrm{~Pb} /{ }^{206} \mathrm{~Pb}$ weighted average age of 
$567 \pm 61 \mathrm{Ma}$ is close to the zircon ages. These ages constrain the age of the province to c. 570 Ma. Other low-Ti basaltic samples, dolerites and a rhyolitic dacite contain much older zircons that crystallized at c. 1290, 1470, 1820-1860, 1930-2050 and 2660 Ma. Ages in between 1820-1860 and 1930-2050 Ma correspond to the ages of the Precambrian basement that underlies the Volyn flood basalt province. However, the source(s) for the 1290, 1470 and 2660 Ma zircons is unknown and must be derived from more distal sites.

Acknowledgments The first author acknowledges financial support from the Swedish Institute (Svenska Institutet). We are grateful to S.M. Tsymbal, K.I. Derevska and geologists of the Rivne geological enterprise for providing samples. Martin Whitehouse, Lev Ilyinski and Kerstin Lindén are thanked for their assistance at the NORDSIM facility. The NORDSIM facility is operated under an agreement between the research funding agencies of Denmark, Norway, Iceland and Sweden, and the Geological Survey of Finland and the Swedish Museum of Natural History. This article is NORDSIM contribution number 426. This is publication number 46 of the large igneous provinces - supercontinent reconstruction - resource exploration project (www.supercontinent.org; www.camiro.org/exploration/ongoing-projects). The manuscript benefitted greatly from careful reviews by two anonymous reviewers and Associate Editor Dr. Martin Klausen.

\section{References}

Amelin, Y.V., Heaman, L.M., Verchogliad, V.M. \& Skobelev, V.M., 1994: Geochronological constraints on the emplacement history of an anorthositerapakivi granite suite: $\mathrm{U}-\mathrm{Pb}$ zircon and baddeleyite study of the Korosten complex, Ukraine. Contributions to Mineralogy and Petrology 116, 411-419.

Andréasson, P.-G., Svenningsen, O.M. \& Albrecht, L., 1998: Dawn of phanerozoic orogeny in the North Atlantic tract; evidence from the SeveKalak superterrane, scandinavian caledonides. GFF 120, 159-172.

Bakun-Czubarow, N., Białowolska, A. \& Fedoryshyn, Y., 2002: Neoproterozoic flood basalts of Zabolottya and Babino beds of the volcanogenic Volhynian series and Polesie series dolerites in the western margin of the East European craton. Acta Geologica Polonica 52(4), 481-496.

Białowolska, A., Bakun-Czubarow, N. \& Fedoryshyn, Y., 2002: Neoproterozoic flood basalts of the upper beds of the Volhynian series (East European craton). Geological Quaternary 46(1), 37-57.

Bingen, B., Demaiffe, D. \& Breemen, O., 1998: The 616 Ma Old Egersund basaltic dike swarm, SW Norway, and Late Neoproterozoic opening of the Iapetus Ocean. The Journal of Geology 106, 565-574.

Birulyov, A.E., 1968: O stratigrafii Volynskoi Serii (Verkhniy dokembriy) Volyni [On the stratigraphy of the Volyn Series (Upper Precambrian) of the Volyn region]. Sovetskaya geologiya 3, 23-33. (In Russian).

Black, L.P., Kamo, S.L., Allen, C.M., Aleinikoff, J.N., Davis, D.W., Korsch, R.J. \& Foudoulis, C., 2003: TEMORA 1: a new zircon standard for Phanerozoic U-Pb geochronology. Chemical Geology 200, 155-170.

Bogdanova, S.V., Page, L.M., Skridlaite, G. \& Taran, L.N., 2001: Proterozoic tectonothermal history in the western part of the East European Craton: 40Ar/39Ar geochronological constraints. Tectonophysics 339, 39-66.

Bogdanova, S.V., Pashkevich, I.K., Buryanov, V.B., Makarenko, I.B., Orlyuk, M.I., Skobelev, V.M., Starostenko, V.I. \& Legostaeva, O.V., 2004: The 1.80-1.74-Ga gabbro-anorthosite-rapakivi Korosten Pluton in the Ukrainian Shield: a 3-D geophysical reconstruction of deep structure. Tectonophysics 381, 5-27.

Bryan, S.E. \& Ernst, R.E., 2008: Revised definition of large igneous provinces (LIPs). Earth-Science Reviews 86, 175-202.

Claesson, S., Bogdanova, S.V., Bibikova, E.V. \& Gorbatschev, R., 2001: Isotopic evidence for Palaeoproterozoic accretion in the basement of the East European Craton. Tectonophysics 339, 1-18.

Compston, W., Sambridge, M.S., Reinfrank, R.F., Moczydeowska, M., Vidal, G. \& Claesson, S., 1995: Numerical ages of volcanic rocks and the earliest fauna1 zone within the Late Precambrian of east Poland. Journal of the Geological Society 152, 599-611.

Elming, S.-Å., Kravchenko, S.N., Layer, P., Rusakov, O.M., Glevasskaya, A.M., Mikhailova, N.P. \& Bachtadse, V., 2007: Paleomagnetism and ${ }^{40} \mathrm{Ar}{ }^{\beta 9} \mathrm{Ar}$ age determinations of the Ediacaran traps from the southwestern margin of the East European Craton, Ukraine: relevance to the Rodinia break-up. Journal of the Geological Society 164, 969-982.

Elming, S.-A., Shumlyanskyy, L., Kravchenko, S., Layer, P. \& Söderlund, U., 2010: Proterozoic basic dykes in the Ukrainian Shield: a paleomagnetic, geochronologic and geochemical study - the accretion of the Ukrainian Shield to Fennoscandia. Precambrian Research 178, 119-135.

Ernst, R.E., 2014: Large igneous provinces. Cambridge University Press, Cambridge, 653 pp.

Ernst, R.E., Buchan, K.L. \& Campbell, I.H., 2005: Frontiers in large igneous province research. Lithos 79, 271-297.

Hodych, J.P., Cox, R.A. \& Košler, J., 2004: An equatorial Laurentia at $550 \mathrm{Ma}$ confirmed by Grenvillian inherited zircons dated by LAM ICP-MS in the
Skinner Cove volcanics of western Newfoundland: implications for inertial interchange true polar wander. Precambrian Research 129, 93-113.

Jaffrey, A.H., Flynn, K.F., Glendenin, L.E., Bentley, W.C. \& Essling, A.M., 1971: Precision measurements of half-lives and specific activities of ${ }^{235} U$ and ${ }^{238} U$. Physical Review 4, 1889-1906.

Johansson, A., 2009: Baltica, Amazonia and the SAMBA connection - 1000 million years of neighbourhood during the Proterozoic? Precambrian Research 175, 221-234.

Kamo, S.L., Gower, C.F. \& Krogh, T.E., 1989: Birthdate for the lapetus Ocean? A precise U-Pb zircon and baddeleyite age for the Long Range dikes, southeast Labrador. Geology 17, 602-605.

Kruglov, S.S., \& Tsypko, A.K (Eds.), 1988: Tektonika Ukrainy [Tectonics of Ukraine]. Nedra, Moscow, 254 pp. (In Russian).

Krzeminska, E., Williams, I. \& Wiszniewska, J. 2005: A late Paleoproterozoic $(1.80 \mathrm{Ga})$ subduction-related mafic igneous suite from Lomza. NE Poland. Terra Nova 17, 442-449.

Li, Z.X., Bogdanova, S.V., Collins, A.S., Davidson, A., De Waele, B., Ernst, R.E., Fitzsimons, I.C.W., Fuck, R.A., Gladkochub, D.P., Jacobs, J., Karlstrom, K.E., Lu, S., Natapov, L.M., Pease, V., Pisarevsky, S.A., Thrane, K. \& Vernikovsky, V., 2008: Assembly, configuration, and break-up history of Rodinia: a synthesis. Precambrian Research 160, 179-210.

Ludwig, K.R., 2012: Isoplot 3.75. A geochronological toolkit for Microsoft Excel Berkeley Geochronology Center, Spec. Pub. p. 75.

Makhnatch, A.S., 1968: Effuzivnye porody srednego sostava Vendskogo komleksa Brestskoy vpadiny [Intermediate effusive Vendian rocks of the Brest depression]. Doklady Akademii Nauk BSSR 12(2), 148-151. (In Russian).

Nitke, V.N., Markovsky, V.M. \& Makovskaya, N.A., 1976: Late Proterozoic deposits of the western Ukraine according to the deep drilling data. Tektonika $i$ stratigrafiya 11, 61-74. (In Russian).

Nosova, A.A., Kuzmenkova, O.F., Veretennikov, N.V., Petrova, L.G. \& Levskiy, L.K., 2008: Neoproterozoiskaya Volynsko-Brestskaya magmaticheskaya provintsiya na zapade Vostochno-Evropejskogo kratona: osobennosti vnutriplitnogo magmatizma v oblasti drevnej shovnoj zony [Neoproterozoic Volyn-Brest igneous province in the west of the East-European craton: peculiarities of the intraplate magmatism in the area of ancient shear zone]. Petrology 16, 115-147, (In Russian).

Pinto, V.M., Hartmann, L.A., Santos, J.O.S., McNaughton, N.J. \& Wildner, W., 2011: Zircon U-Pb geochronology from the Paraná bimodal volcanic province support a brief eruptive cycle at $\sim 135 \mathrm{Ma}$. Chemical Geology 281, 93-102.

Poprawa, P. \& Pacześna, J., 2002: Rozwój ryftu w późnym neoproterozoicuwczesnym paleozoiku na lubelsko-podlaskim skłonie kratonu wschodnioeuropejskiego - analiza subsydencji i zapisu facjalnego [The Development of a Rift in the Late Neoproterozoic - Early Paleozoic at the Lublin- Podlasie Slope of the East European Craton: Analysis of Subsidence and Facies Record]. Przeglad Geologiczny 50, 49-63.

Postnikova, N.E., 1977: Verkhniy Dokembriy Russkoi platformy $i$ ego neftenostnost [Upper Precambrian of the Russian platform and its oil potential]. Nedra, Moscow, 222 pp. (In Russian).

Puffer, J.H., 2002: A late neoproterozoic eastern Laurentian superplume: location, size, chemical composition, and environmental impact. American Journal of Science 302, 1-27.

Rodionov, N.V., Belyatsky, B.V., Antonov, A.V., Kapitonov, I.N. \& Sergeev, S.A., 2012: Comparative in situ U-Th-Pb geochronology and trace element composition of baddeleyite and low-U zircon from carbonatites of the Palaeozoic Kovdor alkaline-ultramafic complex, Kola Peninsula, Russia. Gondwana Research 21, 728-744.

Scherbak, N.P., Artemenko, G.V., Lesnaya, I.M., Ponomarenko, O.M. \& Shumlyanskyy, L.V., 2008: Geokhronologiya Rannego Dokembriya. Proterozoy [Geochronology of the Early Precambrian. Proterozoic]. Naukova Dumka, Kyiv, 240 pp. (In Russian).

Semenenko, N.P. (Ed.), 1975: Kriterii prognozirovaniya mestorozhdeniy Ukrainskogo schita $i$ ego obramleniya [Criteria of prediction of mineral deposits in the Ukrainian shield and its neighbouring]. Naukova Dumka, Kyiv, 550 pp. (In Russian).

Shumlyanskyy, L.V., 2008: Geokhimichni osoblyvosti ta genezis bazaltiv ratnenskoi svity vendskoi trapovoi formatsii Volyni [Geochemistry and origin of basalts of the Ratne Suite of the Vendian Volynian continental flood province]. Mineralogichnyi zhurnal 30(1), 48-65. (In Ukrainian).

Shumlyanskyy, L.V., 2012: Evolyutsiya vendskogo trapovogo magmatizmu Volyni [Evolution of the Vendian continental flood basalt magmatism in the Volyn region]. Mineralogichnyi zhurnal 34(4), 50-68. (In Ukrainian).

Shumlyanskyy, L. \& Derevska, K., 2001: Pershi Sm-Nd ta Rb-Sr izotopnogeokhimichni dani stosovno Vendskykh bazaltiv Volyni [The first Sm-Nd and $\mathrm{Rb}-\mathrm{Sr}$ isotope-geochemical data regarding Vendian basalts of the Volyn region]. Naukovi Pratsi Instytutu Fundamentalnykh Doslidzhen 4, 67-75. (In Ukrainian).

Shumlyanskyy, L.V., Belousova, O.A. \& Elming, S.-Å., 2008: Novi vidomosti pro izotopnyi vik porid paleoproterozoiskoi gabro-dolerytovoi asociatsii PivnichnoZakhidnogo rajonu Ukrainskogo schita [New data on isotope age of rocks of the Palaeoproterozoic gabbro-dolerite association of the Northwestern region of the Ukrainian shield]. Mineralogichny zhurnal 30(4), 58-69. (In Ukrainian).

Shumlyanskyy, L., Hawkesworth, C., Dhuime, B., Billström, K., Claesson, S. \& Storey, C., 2015: ${ }^{207} \mathrm{~Pb} /{ }^{206} \mathrm{~Pb}$ ages and $\mathrm{Hf}$ isotope composition of zircons from sedimentary rocks of the Ukrainian shield: Crustal growth of the south- 
western part of East European craton from Archaean to Neoproterozoic. Precambrian Research 260,39-54.

Shumlyanskyy, L.V., Kuzmenkova, O.F., Tsymbal, S.M., Melnychuk, V.G. \& Tarasko, I.V., 2011: Geohimiya ta izotopnyi sklad Sr i Nd v intruzyvnykh tilakh vysokotytanystykh dolerytiv Volyni [Geochemistry and $\mathrm{Sr}$ and $\mathrm{Nd}$ isotope composition in intrusions of high-Ti dolerites of the Volyn area]. Mineralogichnyi zhurnal 33(2), 72-82. (In Ukrainian).

Shumlyanskyy, L.V. \& Zagnitko, V.M., 2010: Izotopnyi vik, geokhimichnyi I mineralogichnyi sklad pegmatytiv v anortozytakh Volodarsk-Volynskogo masyvu, Korostenskyi pluton [Isotope age, geochemical and mineralogical composition of pegmatites in anorthosites of the Volodarsk-Volynsky massif, the Korosten pluton]. Mineralogichnyi zhurnal 33(1), 15-29. (In Ukrainian).

Skridlaite, G., Baginski, B. \& Whitehouse, M., 2006: The ca 1.5 Ga zircons and monazites in charnockites from the western East European Craton. Geophysical Research Abstracts 8, 07385.

Söderlund, U. \& Johansson, L., 2002: A simple way to extract baddeleyite (ZrO2). Geochemistry, Geophysics, Geosystems 3(2). doi:10.1029/2001GC000212.

Stacey, J.S. \& Kramers, J.D., 1975: Approximation of terrestrial lead isotope evolution by a two-stage model. Earth Planetary Science Letters 26, 207-221.

Starytskyy, Y.G (Ed.), 1981: Istoriya razvitiya i minerageniya chekhla Russkoi platformy [The history of evolution and minerageny of the sedimentary cover of the Russian platform]. Leningrad, Nedra, 224 pp. (In Russian).

Svenningsen, O.M., 2001: Onset of seafloor spreading in the Iapetus Ocean at 608 Ma: precise age of the Sarek Dyke Swarm, northern Swedish Caledonides. Precambrian Research 110, 241-254.

Teixeira, W., Ernst, R.E., Hamilton, M.A., Lima, G., Ruiz, A.S. \& Geraldes, M.C., 2015: Widespread ca. $1.4 \mathrm{Ga}$ intraplate magmatism and tectonics in a growing Amazonia. GFF. doi:10.1080/11035897.2015.1042033.
Vlasov, B.I., Volovnik, B.Y. \& Gruzmanm, G.G., 1972: Osobennosti stroeniya i printsipy razdeleniya Polesskoi Serii Volyni [The composition and principles of division of the Polissya Series of the Volyn region]. Geologicheskiy zhurnal 32(4), 56-67. (In Russian).

Whitehouse, M.J. \& Kamber, B.S., 2005: Assigning dates to thin gneissic veins in high-grade metamorphic terranes: a cautionary tale from Akilia, southwest Greenland. Journal of Petrology 46, 291-318.

Wiedenbeck, M., Allé, P., Corfu, S., Griffin, W.L., Meier, M., Oberli, F., von Quadt, A., Roddick, J.C. \& Spiegel, W., 1995: Three natural zircon standards for U-Th- $\mathrm{Pb}$, Lu-Hf, trace element and REE analysis. Geostandards and Geoanalytical Research 19, 1-23.

Wingate, M.T.D., Campbell, I.H., Compston, W. \& Gibson, G.M., 1998: Ion microprobe $\mathrm{U}-\mathrm{Pb}$ ages for Neoproterozoic basaltic magmatism in southcentral Australia and implications for the breakup of Rodinia. Precambrian Research 87, 135-159.

Wiszniewska, J., Kusiak, M.A., Krzemińska, E., Dörr, W. \& Suzuki, K., 2007: Mesoproterozoic AMCG granitoids in the Mazury complex, NE Poland - a geochronological update. Granitoids in Poland, AM monograph No. 1, 31-39.

Zheng, J.P., Griffin, W.L., Li, L.S., O'Reilly, S.Y., Pearson, N.J., Tang, H.Y., Liu, G.L., Zhao, J.H., Yu, C.M. \& Su, Y.P., 2011: Highly evolved Archean basement beneath the western Cathaysia Block, South China. Geochimica et Cosmochimica Acta 75, 242-255.

Znamenskaya, T.A. \& Chebanenko, I.I., 1985: Blokovaya tektonika VolynoPodolii [The block tectonics of the Volyno-Podolian region]. Naukova Dumka, Kyiv, 156 pp. (In Russian). 